\title{
Issues of Digital Trade Rules and Implications for Korea in the Post COVID-19 World
}

Author(s): Jungran Cho, Byunghee Ahn, Kyoungseo Hong, Inkyo Cheong

Source: Journal of International Logistics and Trade 2020; 18(3):137-147

Published by: Jungseok Research Institute of International Logistics and Trade, Inha University

DOI: https://doi.org/10.24006/jilt.2020.18.3.137

The Journal of International Logistics and Trade is an official journal published by Jungseok Research Institute of International Logistics and Trade, Inha University, Korea. JILT welcomes manuscripts that advance the practice and science of logistics, trade, and other related fields.

Frequency: Quarterly (March, June, September, December)

Stable URL: https://www.ejilt.org

The Jungseok Research Institute of International Logistics and Trade is a specialized academic research institute representing Inha University and the Inha Foundation in Korea. The institute aims to become a representative institute in Northeast Asia in the research of logistics and trade.

Stable URL: https://jrieng.inha.ac.kr

(C) Copyright. Jungseok Research Institute of International Logistics and Trade.

This is an Open-Access article distributed under the terms of the Creative Commons Attribution NonCommercial License (http://creativecommons.org/licenses/by-nc/4.0/) which permits unrestricted noncommercial use, distribution, and reproduction in any medium, provided the original work is properly cited 


\title{
Journal of International Logistics and Trade
}

J. Int. Logist. Trade, 2020, Vol. 18, No. 3, 137-147

pISSN : 1738-2122 eISSN : 2508-7592

https://doi.org/10.24006/jilt.2020.18.3.137

https://www.ejilt.org

ARTICLE

\section{Issues of Digital Trade Rules and Implications for Korea in the Post COVID- 19 World}

\author{
Jungran $\mathrm{Cho}^{1}$, Byunghee Ahn², Kyoungseo Hong ${ }^{3}$, Inkyo Cheong,* \\ ${ }^{1}$ Program in FTA Policy and Business Consulting, Graduate School, Inha University, Incheon, Korea \\ ${ }^{2}$ Program in FTA Policy and Business Consulting, Graduate School, Inha University, Incheon, Korea \\ ${ }^{3}$ Program in International Relations, Graduate School of Arts and Science, New York University, New York, NY, USA \\ ${ }^{4}$ Department of International Trade, Inha University, Incheon, Korea
}

\section{Received August 24, 2020 \\ Revised September 14, 2020 \\ Accepted September 18, 2020
*Corresponding author: Inkyo Cheong Department of International Trade, Inha University, Incheon, Korea
Tel: +82-32-860-7785
E-mail: inkyoc@gmail.com

\begin{abstract}
As a countermeasure to the COVID-19 pandemic, countries are implementing social distancing and mask-wearing. In this situation, the use of digital devices and untact activities are increasing. As a result, domestic and international e-commerce is increasing, and data is growing rapidly. Developed countries with advanced artificial intelligence and big data technologies have been striving to establish international regulations for digital trade in order to create a business environment that is advantageous for their own companies. This paper examines the e-commerce trend since the outbreak of COVID-19 and analyzes major issues related to digital trade rules under discussion. In particular, this paper pointed out that although Korea is recognized to be an advanced country considering its stage of industrial development and income level, the nation maintains the position of developing countries regarding digital trade. Based on this, this paper attempted to draw implications for the development of Korea's digital trade in the post COVID-19 world.
\end{abstract}

Keywords Digital trade, COVID-19, Association of Southeast Asian Nations (ASEAN), Business-to-business (B2B), Business-to-consumers (B2C)

\section{Introduction}

OCED (2020) underlines the role of digital trade in helping to mitigate some of the consequences of COVID-19. The reason why digital trade helps in overcoming the coronavirus crisis is that it allows "untact" social and economic activities, and in order to prepare for any new epidemic that may break out in the future, the untact infrastructure must be improved. World Economic Forum (2020a) states that the COVID-19 has induced people to use more digital technologies and services, making digital trade grow under social distancing and lockdown. One of the conclusions by the forum is that it is necessary to modernize digital trade rules for advancing digital trade, creating more jobs and improving human connections after COVID-19. OCED (2020) and World Economic Forum (2020a) both suggest that digital trade is important after the outbreak of coronavirus and that regulations for digital trade must quickly be finalized.

Digital trade includes all forms of e-commerce through digital trade platforms and the related data. The use of digital devices creates data and platforms accumulate it. The $4^{\text {th }}$ industrial revolution tries to "datatize" production processes through sensors. Processing and fusing data, digital trade creates new value added by combining to artificial intelligence (AI) and big data technologies. It is necessary to set international regulations on digital trade in order to facilitate the utilization of data. Advanced countries have been establishing international regulations in the field of trade as well as leading the discussion on regulations of digital trade.

Developed countries underline the economic value of digital trade and promotes advantageous regulations for the companies in their countries, but many consider digital trade as e-commerce. Korea also stays at this level and focuses more on policies to protect domestic e-commerce market rather than on economic effects of digital trade. Regardless of what positions countries take, COVID-19 is expediting the use of e-commerce for procuring food and basic items. Developed countries understand this as an opportunity for digital trade, yet the rest see it as an expansion of just international trade, initiating a problem of digital divide. Korea is an exemplary country that is stuck in the middle. Although Korea's information and communications industry 
is of a world-class level, digital trade is confined to the level of developing countries. According to McKinsey Global Institute (MGI 2016), Korea, the 7th largest trading country in the world, ranked 44th in data trade as of 2016.

Unlike other developing countries, Korea is a global ICT power. The nation has businesses that are ranked the first and second in the production of semiconductors in the world, and one of global smart phone producers. Korean government could have stopped the early spread of coronavirus by using the ICT digital technology (Ministry of Economy and Finance 2020). However, using big data entails many regulations. In early 2020, the MyData business became possible through revising the 3 pieces of laws related to e-commerce, but the nation still adheres to taking a defensive stance.

Digital trade will expand in the post-COVID-19 era, and its economic feasibility is indisputable. This also can be directly connected to the Fourth Industrial Revolution which is currently taking place. This paper seeks to study the issues of digital trade that will be vitalized in the post-COVID-19 era. In Chapter 2, the paper discusses the trends of post-COVID-19 ecommerce, and in Chapter 3, it tries to analyze positions and issues of major countries on digital trade regulations. Then, in Chapter 4, the study will discuss Korea's task in terms of digital trade regulations and lastly in Chapter 5, it seeks to elicit a conclusion and implications.

\section{COVID-19 and e-commerce}

Although the term 'e-commerce' is more frequently used than 'digital trade', the term 'digital trade' is used, when ecommerce relates to big data. Digital trade can be seen as a concept which fuses e-commerce and big data. Since the outbreak of coronavirus, the usage of digital devices has increased globally, and as the lockdowns are protracted, e-commerce has also increased. Moreover, the international society has become increasingly interested in regulations of digital trade. Here, this chapter seeks to briefly summarize the current situation of COVID-19 and analyze foreign and Korean trends of e-commerce since the outbreak of the virus.

\subsection{Worldwide COVID-19 situation}

As of August 10, 2020, the worldwide cases of COVID-19 went over 20 million and the number of deaths has reached 743 thousand (Worldometer Coronavirus data). Despite the fluctuations, the worldwide case curve has not reached the inflection point, and daily cases are still rapidly increasing. During April and May, when countries had implemented border closures due to the worldwide spread of the virus, the world daily cases fell short of an average of 100,000; however, in July, the daily cases went above 200,000, and in August, there are more than 300,000 cases a day. In April, due to the sharp increase in the number of cases, the medical system had been broken down in many countries, resulting in 7,500 deaths in a day. Then, after normalization of medical system, the number of deaths was lowered to 5,000 while increasing back to 6,000-7,000 in August.

In the first half of the year, many countries had thought that they would be able to eradicate COVID-19 through a lockdown for about a month; however, as the spread of the virus was relentless, they increased the lockdown period. Nevertheless, as summer approached, there was an increase in complaints against self-isolation, and considering the effects on economy, many countries have gradually relaxed the lockdown regulations. From viewing the spreading trends of coronavirus so far, the possibility of re-imposing a lockdown always exists.

As economic activities stopped in the first half of this year, the global economy experienced a negative growth (IMF 2020). As it became known that COVID-19 is spread by contacts or liquid droplets, people have reduced interpersonal transactions and activated the "untact" transactions. The untact conferences, online education and e-commerce have been actively vitalized. E-commerce, which has been growing consistently since its start 20 years ago, is experiencing an increase in users and transaction amounts. Many global representatives of offline sales companies, such as Walmart, have increased businesses that fit the new transaction environment by supplementing sales departments for e-commerce, and the amount of sales of global ecommerce companies, including Amazon, in the first half of this year was a record high.

The offline businesses that highly depend on labor are facing difficulties not only reduced customers, but also from reduced labor supply due to COVID-19. Del Rio-Chanona et al. (2020) view that lockdown policies would shrink the labor supply by $21 \%$. In particular, food and beverage industries, tourism and service industries have been impacted to a great extent, and the rate of reduction for female participation in labor may be high due to the pressure of caring children during lockdowns (Coskun \& Dalgic 2020; ILO 2020). ILO (2020) predicted that the worldwide total of working hours of the second quarter would reduce by $10.7 \%$ compared to last year. Spread of another epidemic after COVID-19 is plausible, thus it seems that the trend of online and e-commerce would be consolidated in the future transactions. 


\subsection{E-commerce after the outbreak of COVID-19}

Through the advancement of information and communications technology and spread of smartphones, the Internet users have increased, and with the development of safe and convenient payment systems, such as an electronic wallet, e-commerce has been able to grow at a fast pace. According to International Telecommunication Union (ITU 2020), the worldwide Internet users in 2005 were 1.68 billion, accounting only about 15\% of the total global populations. However, in 2019, the number rapidly increased to 4.13 billion. It is expected that approximately 2 billion people, which is a half of the total Internet populations, are the users of online shopping.

Since the outbreak of COVID-19, the e-commerce software and hardware has been globally expanded in terms of signing contracts, shipping, making payments and etc., and "e-commerce --- is emerging as a key pillar in the global fight against COVID-19" in this coronavirus crisis today. As online shopping, telemedicine and online education increase, face-to-face contacts are avoidable, ultimately leading to reduction in COVID-19 transmission. For those countries or regions that had initiated home isolation or lockdowns, e-commerce played a critical role in people's survival. Therefore, it is emphasized that the government has to support e-commerce enterprises to be able to persist their businesses (Ungerer and Portugal 2020). According to Deloitte (2020) that has researched Denmark's e-commerce during the coronavirus crisis, it views that COVID19 would establish e-commerce as a permanent business model. The research takes an example of the success of Alibaba and Chinese JD Multimedia (currently JD.com) in their early success due to the 2003 SARS crisis and accentuates that such crisis played a vital role in permanently forming new business model and economic order. In other words, this coronavirus crisis could be an opportunity for e-commerce to grow further.

The typical offline retailers are also strengthening their online sales since the pandemic. According to Garcia (2020), Walmart USA has been ranked the second - surpassing eBay - in terms of the scale of the United States e-commerce sales; the first being Amazon. In cooperation with Canada's Shopify, Walmart has been planning a system that could assail the stronghold of Amazon. Many other multinational retailers are also bolstering e-commerce.

As social distancing and lockdowns increase as the COVID-19 preventative measures, consumers stay more at home and their use of digital services, such as online shopping, social media and etc., are accordingly expanded (Ungerer and Portugal 2020). Thus, Business-to-Consumers (B2C) and Business-to-Business (B2B) increased. COVID-19 has built a steppingstone for e-commerce to establish itself as a critical means for consumers in a crisis. In order to overcome the COVID-19 crisis, international cooperation for e-commerce and policies for activating online transactions must be discussed at a global scale (WTO 2020). World Bank (2020) suggests 13 measures to support e-commerce at a national level. ${ }^{1}$ The measures state that ecommerce reduces a person-to-person contact and contributes to prevention of the spread of coronavirus; they also evaluate positive roles that the future e-commerce plays such as advocating people under a lockdown or self-isolation, and they suggest each country should support e-commerce companies during the time of emergency. MGI (2020) proposes construction of ecommerce infrastructure as a means for businesses to survive in the coronavirus crisis.

E-commerce has been able to expand since food and necessities had not been able to be procured in offline markets during lockdowns and people had been reluctant to have face-to-face interactions. According to research by Enberg (2020b), the ratio of people's reluctance to be in a place with others was as followed: China (85\%), Hong Kong (83\%), Taiwan (76\%), Malaysia (73\%) and Thailand (70\%). This research revealed that the ratio of the United States and the United Kingdom were $27 \%$ and $14 \%$ respectively, but it is interpreted that the results are low since the study had been conducted before the awareness for COVID-19 was augmented. ${ }^{2}$ Nevertheless, if coronavirus is spread, $75 \%$ of the responders agreed to avoid visiting shopping centers. In particular, $86 \%$ of the responders over 61 -years-old answered to avoid it.

For the United States, the revenue of online retails increased by $68 \%$ as of mid-April, and for the United States and Canada together, e-commerce orders and the entire online retail orders increased by $129 \%$ and 146\% respectively. During the lockdown, most households ordered via online. COVID-19 has been altering the means of retails into e-commerce (Columbus 2020). For Indonesia, the revenues of hypermarket or supermarket decreased from $-12 \%$ to $-15 \%$, while their revenue of e-commerce increased by 22\% (Kanter 2020).

Abdelrhim and Elsayed (2020) analyze how the COVID-19 crisis has influenced revenues of the world's top 5 e-commerce

\footnotetext{
${ }^{1}$ Examples of the 13 measures include management of a website offering information, relaxation of e-commerce regulations, establishment of digital economic laws, such as medical services, and etc.

${ }^{2}$ This research was conducted in February 2020 when COVID-19 had not been actively spread in the United States or Europe.
} 
businesses. $^{3}$ According to this research, the influence of e-commerce is greater in an order of the total number of deaths from COVID-19, the cumulative number of confirmed cases and new cases. For United States Amazon and UK ASOS, the cumulative number of cases was found to exert the greatest influence, and for Zalando of Germany, the cumulative number of deaths had the greatest impact. How the spread of COVID-19 increases e-commerce and digital transactions (online doctor) is also clearly demonstrated by Ungerer and Portugal (2020).

As of February 2020, eMarketer (2020a) predicted that the earning of retail business in the United States had been expected to increase by $2.8 \%$ compared to last year, ultimately leading to an increase of sales worth of $\$ 5.6$ trillion. However, due to COVID-19, its contraction in retails has become unavoidable. Samet (2020), considering the impact of COVID-19, has made a prospect that the revenue from e-commerce would be higher by $18 \%$, which is an augmented measure than last year's $14.9 \%$ by $3.1 \%$, although total sales in retails reduced by $10.5 \%$.

COVID-19 has created a chance to accelerate digitization, such as online education and untact conferences. According to a survey of World Economic Forum (2020b), younger generations of the Association of Southeast Asian Nations (ASEAN) were able to earn the experience of digitization. About $87 \%$ of the responders have used more than one digital device, and $42 \%$ purchased new digital devices. Approximately 33\% of all businesses in ASEAN were able to increase their sales through ecommerce, and more than $64 \%$ of the responders claimed that online education, electronic financial service or food delivery will be inevitable in the future. It is strongly believed that COVID-19 will accelerate and continue digitization and e-commerce. ${ }^{4}$

On the other side, when the number of cases rapidly increases regionally, e-commerce delivery of a particular item also increases. Nielsen (2020) claimed that deliveries of cleaning products, groceries and diapers are deeply related to the number of regional cases. Deloitte (2020) that has analyzed Denmark's e-commerce since the outbreak of COVID-19 reports the items that experienced a surge were, in an order from the greatest to lowest, books/movies/music, groceries/food/beverages, building supplies, hobby/office/photo, electronics/compliances/IT and personal care (cosmetics, pharma). For the United States, food and beverage sales - accounting for the biggest surge - have increased by 58.5\%, and clothing by $8.6 \%$ (Garcia 2020). Some of the items purchased the most by about $80 \%$ of the Indonesian consumers that had stayed at home, complying with the nation's preventative measures for the pandemic, include personal care, dairy, home care, beverage, and packaged food (Kanter 2020).

\subsection{Korea's e-commerce}

As Korea's number of cases sharply surged during February, social distancing and self-isolation largely restricted people's economic activities. Due to the outbreak of coronavirus, Korea's first quarter production of service industries, including tourism, cultural activities, wholesale and retail/food/beverage, faced difficulties, yet the information and communications industries experienced a positive outcome.

According to a report by Korea International Trade Association (2020), the first quarter's GDP for service industries decreased by $2.0 \%$ compared to the previous year, making them more vulnerable than the manufacturing industries that experienced a decrease by $1.8 \%$. The production decrease by industries was highest to lowest in the following order: transportation (-12.6\%), wholesale and retail/food/beverage (-6.5\%), culture service (-6.2\%) and more. The industries that the report claimed that will emerge in the future include Korea's top 3 service trends, such as transition to digitization, untact distribution and 'homeconomy'. Korea International Trade Association views that Korea's e-commerce sales will increase by $10.8 \%$ annually, thus from $\$ 50$ billions of 2017 to $\$ 100$ billion in 2024, through the possible continuation of the public's preference in the untact transactions and an increase in purchasing digital devices since the spread of COVID-19.

As of April, the consumer composite sentiment index (CCSI) decreased to 70.8, a measure that's decreased by $7.6 \%$ compared to the previous year. Such measure has been found to be the second-lowest since it was first calculated, and is also of a comparable level with the measure during the 2008 Global Financial Crisis (67.7). COVID-19 has hit the distribution industries very hard, and the sales of duty-free shops have been reduced by $30 \%-40 \%$. Yet, the e-commerce businesses certainly experienced benefits from the pandemic (Ju 2020).

In Korea, collection of statistics of e-commerce transactions in case of imports, is done by the Korea Customs Service. These

${ }^{3}$ World's top 5 e-commerce businesses include American Amazon, Chinese Alibaba, Japanese Rakuten, German Zalando, United Kingdom ASOS.

${ }^{4}$ World Economic Forum (2020b) wrote a report based on the survey of 68,574 youths (age of 16-35) in the ASEAN countries in the first half of this year. 
Table 1. Trend of e-commerce importation

\begin{tabular}{|c|c|c|c|c|c|c|c|c|}
\hline & \multicolumn{2}{|c|}{ Customs clearance } & \multicolumn{2}{|c|}{ Import reports by EDI } & \multicolumn{2}{|c|}{ Total } & \multicolumn{2}{|c|}{ Growth rates (\%) } \\
\hline & Cases & Amount & Cases & Amount & Cases & Amount & Cases & Amount \\
\hline 2009 & 1,453 & 74 & 1,057 & 93 & 2,510 & 167 & - & - \\
\hline 2010 & 1,075 & 56 & 2,504 & 218 & 3,579 & 274 & 42.59 & 64.36 \\
\hline 2011 & 1,818 & 105 & 3,784 & 367 & 5,602 & 472 & 56.52 & 72.22 \\
\hline 2012 & 2,845 & 213 & 5,099 & 494 & 7,944 & 707 & 41.81 & 49.74 \\
\hline 2013 & 3,807 & 331 & 7,352 & 709 & 11,159 & 1,040 & 40.47 & 47.06 \\
\hline 2014 & 6,588 & 570 & 8,942 & 975 & 15,530 & 1,545 & 39.17 & 48.54 \\
\hline 2015 & 9,065 & 715 & 6,777 & 806 & 15,842 & 1,521 & 2.01 & -1.53 \\
\hline 2016 & 9,763 & 719 & 7,632 & 915 & 17,395 & 1,635 & 9.80 & 7.45 \\
\hline 2017 & 13,217 & 887 & 10,375 & 1,223 & 23,592 & 2,110 & 35.63 & 29.10 \\
\hline 2018 & 19,158 & 1,179 & 13,097 & 1,576 & 32,255 & 2,755 & 36.72 & 30.55 \\
\hline 2019 & 25,549 & 1,292 & 17,439 & 1,851 & 42,988 & 3,143 & 33.28 & 14.09 \\
\hline
\end{tabular}

Source: Statistics on e-commerce from Statistics Korea.

Table 2. The weight occupied by e-commerce among express cargos

\begin{tabular}{cccccc}
\hline \multicolumn{1}{c}{} & \multicolumn{2}{c}{ (Unit: 1,000 cases, \$1 million) } \\
\hline Classification & & 2018 & 2019 & 2020.6 & Increase from previous year \\
All express cargos & Cases & 42,031 & 54,486 & 27,663 & 4.5 \\
(A) & Amount & 16,235 & 16,850 & 8,858 & 9.2 \\
E-commerce & Cases & 29,959 & 44,987 & 23,102 & 6.0 \\
(B) & Amount & 2,760 & 3,205 & 1,625 & 2.2 \\
Weight (\%) & Cases & 71.3 & 82.6 & 83.5 & - \\
(B/A) & Amount & 17.0 & 19.0 & 18.3 & - \\
\hline
\end{tabular}

e-commerce imports are mostly B2C transactions, and are normally collated through the customs clearance and Electronic Data Interchange (EDI) import reporting. ${ }^{5}$ After 2009, Korea's cross-border e-commerce experienced a period of stagnation in growth for a couple years, however it has been accomplishing a rapid advancement, reaching an annual average of $33.8 \%$ (in terms of number of cases). In 2019, the number of cases and sales of e-commerce were augmented by $33.3 \%$ and $14.1 \%$ respectively compared to the previous year. Table 1 shows only the B2C transactions, but when the B2B transactions between companies are included, the actual e-commerce is expected to be much greater than what Table 1 shows.

Due to the spread of COVID-19, it is expected that e-commerce in 2020 could be expanded, yet there does not exist an overall data on performance of e-commerce in the first half of this year. Only some documents (Table 2) written by customs officials at Incheon International Airport in charge of express cargo customs clearance are available, and they show that the overall economic activities have certainly been weakened, but e-commerce has increased by $6 \%$ in the first half of 2020. Express cargos that allow the B2C transactions also increased, and the weight of which e-commerce occupies among the express cargos has also been heightened by $8.5 \%$ in the first half. ${ }^{6}$

\section{Issues of international regulations on digital trade (e-commerce)}

World Economic Forum (2020a) suggests facilitating a negotiation toward a multilateral agreement on digital trade. This was one of the agendas discussed at the 2019 Davos Forum, yet the possibility for the agreement is not optimistic. Despite sharing a common ground of the United States, EU and Japan in dissenting against cross-border data flow restriction, developed countries have slightly different aims. This is due to the different competitiveness of digital corporations. Even developed

\footnotetext{
${ }^{5}$ Among the items delivered by EMS (including items via e-commerce), no statistics are available to be confirmed when tax exemption was done on the site.

${ }^{6}$ Express items are transported by customs-registered special delivery companies (UPS, DHL, FEDEX, Lotte, CJ Logistics and more), and they are constituted mainly of e-commerce items, documents, catalogs, samples, gifts and etc.
} 
countries have different views, so a gap between the views of developed and developing countries is inevitably huge.

\subsection{Overview}

WTO, establishing regulations based on a consensus of all members, created a practice to apply no tariffs on electronic transmissions. OECD, an economic organization consisted of developed countries, has set guidelines to protect consumers in e-commerce and has been encouraging members to adopt certain guidelines. APEC has been discussing multiple issues, including reduction of a digital gap, advancement of e-commerce infrastructure for regional economic integration and development of small and medium-sized enterprises, yet it has not taken a practical role going beyond the discussion due to its non-binding characteristic.

Along with development of digital trade, the necessity for establishing international regulations has also gained much attention. Expedition of free flow of information creates a virtuous cycle by improving people's well-being as well as the new innovation and business models. On the other hand, as various activities within the cyber space increase, there are growing concerns over cyber security, such as leakage of personal information or corporate secrets. In order to prevent such concerns, some countries are introducing measures of digital protectionism, such as imposing restrictions of server installing places or regulating cross-border data movements. Countries' regulations on the flow of data between borders have rapidly increased in the last 20 years. These issues are of critical importance that countries take different stances depending on their level of international competitiveness of digital trade, although some of the issues are included in many recent trade agreements.

The articles or chapters on e-commerce included in trade agreements have greatly increased in the last 20 years. $^{7}$ The discussion on digital trade regulations have been developed with issues of market opening, activation of transactions, protection of consumers, data economy and etc. Freeing tariffs on electronic transmissions has been introduced as a catalyst to activate digital trade, and the regulations on consumer protection include protection of personal information, consumer protection at a level that could be done off-line, management of spam messages and dispute resolution. Some of the regulations on activating data economy are movement of data between borders, prohibition of server localization, restriction of compulsory disclosure of source codes and more. The agreement that includes the most articles on e-commerce is the protocol of the Pacific Alliance (PA), and the trade agreements signed by Australia, Canada, Chile, Columbia, Korea, Peru and the United States mostly include chapters on e-commerce or digital trade.

\subsection{Controversial issues of digital trade regulations}

Not only the WTO, but also bilateral trade agreements recently show interests in international regulations on digital trade,

\section{Table 3. Major issues of WTO digital trade}

\begin{tabular}{|c|c|}
\hline Subject & Major issues \\
\hline $\begin{array}{l}\text { Protection of personal } \\
\text { information }\end{array}$ & $\begin{array}{l}\text { Establishment of principles for protection of personal information. Yet, allowing a commercial use of data set } \\
\text { for banning personal identification. }\end{array}$ \\
\hline Consumer protection & Protective measures against possible frauds online. \\
\hline $\begin{array}{l}\text { Cross-border data flow } \\
\text { and storage }\end{array}$ & $\begin{array}{l}\text { One of the most sensitive issues. This is preferred by developed countries, including the United States, but } \\
\text { developing countries diverge on this issue, especially China accentuates sovereignty of data. }\end{array}$ \\
\hline $\begin{array}{l}\text { Electronic signature and } \\
\text { verification }\end{array}$ & $\begin{array}{l}\text { Systemization of ways for electronic signature verification·payment and cross-certification. Most countries use } \\
\text { these, but more closer international cooperation system is required. }\end{array}$ \\
\hline Tariffs & $\begin{array}{l}\text { Maintains zero tariff on electronic transmissions. Further discussion of applying the zero-tariff rule on items } \\
\text { under a certain amount of costs may take place in the future. }\end{array}$ \\
\hline Spam e-mails & $\begin{array}{l}\text { Set standards for managing spam e-mails to improve the health of network environments in establishing } \\
\text { consumer trust in online transactions. }\end{array}$ \\
\hline Public policies & Consider public policies and security issues on data movement. \\
\hline $\begin{array}{l}\text { Digitization of trade } \\
\text { documents }\end{array}$ & Most parts already digitalized. Promote additional trade facilitation using electronic media. \\
\hline
\end{tabular}

Source: Researcher's summary.

\footnotetext{
${ }^{7}$ The US' FTA with Jordan (Article 7 of the FTA), which entered into force in 2001, was the first in the world to contain a provision for crossborder e-commerce, and the first chapter on cross-border e-commerce was adopted in the US-Singapore FTA and the US-Chile FTA, which took effect in January 2004, and e-commerce chapters have been included in US’ all FTAs since then.
} 
because those regulations are necessary for the quaternary sector of industry where goods and services are fused. Within Korea, research has been conducted by Ahn and Kwak (2016), Kim (2018), Wang (2018) and more, and some of the representative research done overseas include Azmeh and Foster (2016), Congressional Research Service (CRS) (2019), Enders and Porges (2016) and etc. Wang (2018) emphasizes a stepwise approach with regulations on technology based on digital, and Kwon (2018) predicts a possibility of an agreement of multiples countries with the United States in lead. On the other hand, Azmeh and Foster (2016) suggest a multilateral form of a digital trade agreement. Further, CRS (2019) points out the position of the United States on digital trade regulations in a systematic manner.

In order to establish efficient digital trade regulations, there needs a review on the major issues across countries. Some of the major issues can include tariff policies, localization requirements, cross-border data flow restrictions, level of protection in personal information, approach of source codes, and standardization of technologies such as electronic payments and accounts.

As the future negotiations begin, there could be some controversy about the definition of digital items, the coverage of applying new rules, zero-tariff for digital transmissions, non-discrimination for digital items, electronic signature and verification, protection of online consumers, use of administrative documents of e-commerce, regulations of net neutrality and more. The application coverage of e-commerce/digital chapter varies across agreements. While the Japan-Switzerland FTA regulates the e-commerce market that applies all goods and services, the PA does not apply on service and investment but only regulates within e-commerce of goods including digital items. And, the Mexico-Panama FTA adopts a chapter similar with that of PA.

\subsection{Positions of major countries on digital trade regulations}

The Table 4 summarizes core policies on digital trade by major country/region. The most important issues in digital trade rules are the ban on localization of data centers, cross-border transmission of data, and the ban on access to source code, which were also reflected in the Comprehensive and Progressive TransPacific Partnership Agreement (CPTPP). In addition to these norms, the United States-Mexico-Canada Agreement (USMCA) also allowed indemnification for platform operators. From the current trade agreements and government policies, Korea agrees to ban access to the source code, but has a negative position on the rest. Korea's refusal to Google's maps implies localization of data centers and restrictions on the movement of data across borders. The United States fundamentally pursues the Open Internet. Owing to the tech giants, GAFA (Google, Apple, Facebook and Amazon), the United States has introduced exemption provisions on the United States e-commerce companies and abrogated access restriction of the Internet in order to facilitate establishing international regulations for digital trade in creating an environment viable for the United States companies to go overseas. Minimizing foreign regulations on the Internet and e-commerce, including prohibition of server localization and permission of cross-border data movement, the United States seeks to internationally standardize protection of intellectual property rights and security of technology for the United States companies that dominate the ICT technology in the world. These regulations have been included in the USMCA, which was

\section{Table 4. Core digital trade policies in major countries}

\begin{tabular}{cl} 
Countries & \multicolumn{1}{c}{ Core digital trade policies } \\
USA & $\cdot$ Focuses on international expansion of the chapter on digital trade in USMCA. \\
& $\cdot$ Facilitates multilateral regulations through communicating with the EU and Japan, along with the already existing \\
& bilateral and multilateral approaches. \\
& $\cdot$ Facilitates a Digital Single Market (DSM) in the territory of the EU. \\
Japan & $\cdot$ Focuses on protection of personal information through GDPR. \\
& $\cdot$ Adopts high-level digital trade regulations in the Japan-United States FTA. \\
China & $\cdot$ Closer cooperation with the United States in forming digital trade regulations. \\
& $\cdot$ Promotes eWTP of the Alibaba while also emphasizing sovereignty of data. \\
ASEAN & $\cdot$ Opposite position with the United States in many aspects. \\
& $\cdot$ ASEAN Connectivity 2025 Master Plan (2016). \\
& $\cdot$ Fosters digital trade as core growth engine.
\end{tabular}

Source: Researcher's summary.

USMCA, United States-Mexico-Canada Agreement; GDPR, General data protection regulation; eWTP, Electronic World Trade Platform; ASEAN, Association of Southeast Asian Nations. 
signed with the United States in lead. Japan's digital trade policies share great similarity with those of the United States. The United States and Japan already includes such rules in their bilateral FTA.

EU has begun building the Digital Single Market toward all the EU member countries in 2015 as a strategy to cope with the US' GAFA. While cooperating with the US, it protects its citizens' personal information through the general data protection regulation (GDPR) which became effective in May 2019 and permits the movement of information within the EU member countries, promoting a strategy to realize digital economy within Europe by expanding e-commerce platforms from its own perspective.

The US-China conflict happens in the field of digital regulations, going above the fields of traditional trade and investment. At the 2016 G20 Hangzhou Summit, China tried to get endorsement from the member countries about the Electronic World Trade Platform (eWTP) of its Alibaba as a global e-commerce platform, and the following year, in August 2017, the United States decided to promote global digital trade. Further, the USMCA, the revised version of NAFTA, included comprehensive digital trade chapter for the first time in the world. Since China keeps to the policies placed in contrary to the US' digital trade regulations, it seems that reaching an agreement of multilateral regulations would be difficult.

The ASEAN countries adopted digital trade as the core growth engine followed by the 'ASEAN Economy Community (AEC) 2025', ‘ASEAN Connectivity 2025 Master Plan’ and etc. ASEAN promotes 5 strategies from the perspective of the ASEAN countries: relaxation of financial transaction barriers; facilitation of regional e-commerce; strengthening digital trade and regional integration; adoption of the ICT and FinTech as the new growth engine; and the inducement of the investment by multinational corporations.

\section{Challenges for Korea regarding digital trade regulations}

\section{1 $4^{\text {th }}$ industrial revolution and digital trade}

Being connected to the $4^{\text {th }}$ industrial revolution, digital trade is becoming a foundation of new industrial development. Through the Internet of Things (IoT) platform, data rapidly increases, and the usage and transaction of data develop into a new industry. During this process, productivity improves and demand of labor changes. For instance, Watson, the cancer detection program of IBM, completes diagnosis of cancer within minutes which a doctor diagnoses after an average of 160 hours.

According to MGI (2016), a drastic increase in cross-border data movement and digital trade has led to a significant change in the business, industry and trade. From 2005 to 2014, the cross-border data movement increased by 45 times, and cross-border transactions of intangible digital goods and cross-border businesses using online platforms have emerged as a new business. Before and after the 2000s, digital trade leads a fundamental change in global value chains. In other words, transitions have been occurring from trade of goods to services, from a global value chain with production cost curtailment to knowledgeintensive re-shoring, from globalized trade to regionalized trade and more (Lund and Tyson 2018; MGI 2019).

The year of 2019 was recognized as the time to commence negotiations for digital trade regulations, but due to the US-China conflict, the WTO was unable to confirm its agenda. And, as the Kazakhstan, the hosting country, postponed the Twelfth WTO Ministerial Conference (MC12) by one year due to its domestic circumstances, the momentum for a negotiation on digital trade regulations has been weakened. Moreover, the outbreak of COVID-19 and the sudden resignation of the WTO Secretary General further deteriorated the progress of the WTO negotiation. The digital trade proposal of the United States submitted to the WTO mostly mentions what has already been included in the USMCA. Many countries submitted their statements of arguments to the WTO, but except for some countries such as Australia, no one agreed to the United States. ${ }^{8}$

However, things have changed since the outbreak of novel coronavirus. On top of the US' already tough measures against China as well as adding the blame of coronavirus on China, the United States has been facilitating decoupling from China. Furthermore, the United States suggests a new trading system with its allies through Economic Prosperity Network (EPN). Most of the USMCA regulations including digital trade would be reflected on EPN. The competitiveness of digital trade has been detected in values of companies, and as the Fourth Industrial Revolution advances, its significance will be heightened. ${ }^{9}$

\footnotetext{
${ }^{8}$ For reference, the Australian government facilitates policies that lead standardization of digital trade through the announcement at the discussion of activating WTO digital trade in April 2018.

${ }^{9}$ According to Hufbauer and Lu (2018), the goods was $-0.2 \%$, FDI $0.6 \%$ and digital trade $4.8 \%$ in terms of the contributiveness of the 2015 world trade growth rate. MGI (2016) reports that data movement from 2005-2015 contributed to the increase of global output by 280 trillion dollars.
} 


\subsection{Korea's countermeasures}

Although small and medium-sized enterprises and self-employers will have an easier access to markets due to digital trade, Korea should take actions against the issues from the digital gap caused from superiority of competitiveness of multinational and platform corporations. In order to deal with the digital gap, relevant companies and industries must be developed, and for this, a domestic legal system needs to be established.

For Korea, Department of Digital Economy and Trade was newly created in the Ministry of Trade, Industry and Energy (MOTIE) in March 2018, and although the Ministry reported 'Directions of Facilitation of Digital Trade Policies' in January 2019, the report is largely behind not only the United States but also the ASEAN countries. ASEAN countries introduced digital trade as their core growth engine focused around fostering e-commerce corporations, ASEAN digital integration, development of ICT and FinTech, cultivating digital labor force and promoting digital start-ups. In other words, ASEAN seeks to build digital trade as a foundation of new industrial development by connecting to the Fourth Industrial Revolution.

Although the development of ICT industries has long been mentioned in Korea, the country has focused on developing hardware, yet only applied many regulations on digital trade and did not construct a systematic foundation for industrial development. According to a report by the Korea International Trade Association (2018) on the 'Digital Trade Restrictiveness Index (DTRI)', the index for Korea was 0.31 , which is a greater value than 0.24 , the average index of the 64 countries who had been surveyed; Korea has been evaluated to implement restrictive policies on digital trade than the global average.

Moreover, even though Korea's FTAs adopt a chapter on e-commerce in the form of complying or supplementing the WTO rules, it is insufficient in many aspects, compared to today's e-commerce environment. E-commerce chapters are being set up in bilateral FTAs signed by Korea with the United States, China, and Vietnam. However, the Korea-US FTA, which has the widest scope of all, has regulations on consumer protection, personal information protection, and prohibition of data server location restrictions, but most of them are stipulated as cooperation clauses, so there is no mechanism to enforce them.

Korea takes positions similar to those of developing countries in many sensitive issues of digital trade. For this, business organizations and experts pointed it out as an impediment in digital industry development and international negotiation on digital trade rules. Thus Korea amended 3 pieces of legislation regarding e-commerce such as the Personal Data Protection Act on January 9, 2020, permitting the use of 'pseudonymization'. The commercial use of data that was originally hidden from being identified of its principles of information has also been permitted under certain conditions. However, the requirements of 'pseudonymization' are more fastidious and stricter, ultimately becoming impediments for corporations to use. Korea must also decide whether the domestic legislation and system would be re-amended or not, based on the analysis of various digital trade regulations of major countries.

\section{Conclusion}

People say coronavirus is changing the world. The peril of a pandemic can always occur, therefore social distancing and untact transactions will increase, implying growing importance of digital trade. Data is less worthy on its own due to its nature, yet can create infinite value and jobs when fused. It is indisputable that data is the foundation of new innovation and growth source. E-commerce, which has been demonstrating a rapid growth until now, is expected to further accelerate its growth in the future due to the coronavirus pandemic and people's preference in untact transactions (World Bank 2020). This paper examines the trend of e-commerce after COVID-19 and analyzes the main issues of international regulations and positions of major countries. Korea, a manufacturing and ICT power, unfortunately does not go beyond the level of developing countries in terms of domestic regulations on digital trade.

Developed countries, including the United States, consider digital trade as one of the cores for new growth engine and devote their efforts into various of diplomatic affairs in order to lead the global digital trade regulations. Further, coronavirus functions in a way of expediting the decoupling between the United States and China. A quarter of the world's COVID-19 cases and deaths have occurred in the United States, and the United States has been incessantly blaming China for this. In this process, the United States is facilitating the EPN, excluding China. It is clear that the EPN will include digital trade regulations.

The United States suggested a negotiation on digital trade regulations to the WTO, and included digital trade rules in the FTAs signed in the recent several years. Developed countries, leading the technology of AI and big data, emphasize the commercial value of data included in e-commerce. In 2019, Korea decided to participate in the WTO DTA negotiations. The revision of data-related laws in early 2020 opened the way for data business, albeit limitedly, but Korea's digital trade regulations are still far behind international discussions. Above all, we need to reform the regulations on data center localization 
and international movement of data. In addition, EU GDPR eligibility certification must be obtained early. It should reform domestic institutions and participate in international discussions. Otherwise, it will take a bystander attitude in international negotiations and eventually withdraw from the negotiations.

New industries have many components that run counter to the existing industrial environment, causing a conflict of interests to be inevitable. To this sensitive matter, developed countries politically seek solutions in an early phase. Although Korea is on the verge of begin a developed country, it is still behind in many aspects. In order to save the Korean economy in a recession caused from the novel coronavirus, it is timely to promote the development of a Digital New Deal policy. Not only through financial support, but also paving institutional foundations are needed. This would be more conducive to development of new industries, and this will be a true New Deal.

\section{Acknowledgements}

This work was supported by the Ministry of Education of the Korea and the National Research Foundation of Korea (NRF2018S1A5A2A03036006).

\section{References}

Abdelrhim, M., Elsayed, A., 2020. The effect of COVID-19 spread on the e-commerce market: The case of the 5 largest ecommerce companies in the world. Available at: https://doi.org/10.2139/ssrn.3621166

Accenture, 2020. Channel Shift: Prioritizing Digital Commerce. COVID-19. Available at: https://www.accenture.com/been/about/company/coronavirus-digital-commerce-impact

Azmeh S., Foster C., 2016. The TPP and the digital trade agenda: Digital Industrial policy and Silicon Valley's influence on new trade agreement. International Development, London School of Economics and Political Science, Working Paper Series No. 16-175.

Columbus, L., 2020. How COVID-19 is Transforming E-Commerce. Forbes. Available at: https:/www.forbes.com/sites/ louiscolumbus/2020/04/28/how-covid-19-is-transforming-e-commerce/

Congressional Research Service, 2019. Digital Trade. CRS In Focus. Available at: https://crsreports.congress.gov/ product/pdf/IF/IF10770

Coskun, S., Dalgic H., 2020. The emergence of procyclical fertility: The role of gender differences in employment risk. Discussion Paper Series CRC TR 224 No. 142.

Del Rio-Chanona, R. M., Mealy, P., Pichler, A., Lafond, F., Farmer, J. D., 2020. Supply and demand shocks in the COVID-19 pandemic: An industry and occupation perspective. Covid Economics, 6, 65-104.

Deloitte, 2020. COVID-19 will Permanently Change E-Commerce in Denmark. Availalbe at: https://www2.deloitte. com/content/dam/Deloitte/dk/Documents/strategy/e-commerce-covid-19-onepage.pdf

eMarketer, 2020a. Predicted that the earning of retail business in the United States had been expected to increase by $2.8 \%$ compared to last year, ultimately leading to an increase of sales worth of \$5.6 trillion.

Enberg, J., 2020. COVID-19 concerns may boost ecommerce as consumers avoid stores: How stock shortages and supply chain issues impact digital advertisers. eMarketer. Available at: https:/www.emarketer.com/content/coronavirus-covid19-boostecommerce-stores-amazon-retail

European Center for International Political Economy [ECIPE], 2018. Digital Trade Restrictiveness Index. Brussels, Belgium.

Ferencz, J., 2019. The OECD digital services trade restrictiveness index. OECD Trade Policy Papers No. 221.

Garcia, T., 2020. Walmart Surpasses eBay in U.S. E-Commerce for the First Time, Amazon still tops: eMarketer. Market Watch. Available at: https://www.marketwatch.com/story/walmart-surpasses-ebay-in-us-e-commerce-for-the-first-time-amazonstill-tops-emarketer-2020-06-15

Hufbauer, G. C., Lu, Z., 2018. Can digital flows compensate for lethargic trade and investment? Available at: https://www.piie.com/blogs/trade-investment-policy-watch/can-digital-flows-compensate-lethargic-trade-and-investment

International Labour Organization [ILO], 2020. The COVID-19 Response: Getting Gender Equality Right for a Better Future for Women at Work. Geneva, Switzerland.

International Monetary Fund [IMF], 2020. World Economic Outlook. Washington, DC.

International Telecommunication Union [ITU], 2020. Measuring Digital Development: Facts and Figures 2019. Geneva, Switzerland. 
Ju, Y., 2020. Lowest since Global Financial Crisis (Consumer Sentiment Index 70.8).

Kantar, 2020. COVID19 Impact on Indonesian Attitudes \& Behaviours. Jakarta, Indonesia.

Kim, J, 2018. Issues and tasks in cross-border digital trade. Studies in International Trade, 23, 55-79.

Korea International Trade Association, 2018. Digital trade restrictiveness index and evaluation of Korea's policy on digital trade. Trade Report Vol. 14.

Korea International Trade Association, 2020. Ecology of Korean Services Industry in the Post Corona Era.

Kwok, D., Ahn D., 2016. Digital trade in analog system: Liberalization of digital trade and role of trade agreement. Trade Law, 131, 51-90.

Kwon, H., 2018. Limitions of multilateral approach in forming rules on e-commerce. Trade Law 78, 377-404.

Lund, S., Tyson, L., 2018. Globalization is not in retreat: Digital technology and the future of trade. Foreign Affairs. Available at: https://www.foreignaffairs.com/articles/world/2018-04-16/globalization-not-retreat

McKinsey Global Institute [MGI], 2016. Digital Globalization: The New Era of Global Flows. New York, NY.

McKinsey Global Institute [MGI], 2019. Globalization in Transition: The Future of Trade and Value Chains. New York, NY.

McKinsey Global Institute [MGI], 2020. Building an E-commerce Business: Lessons on Moving Fast. New York, NY.

Ministry of Economy and Finance, 2020. Flattening the Curve on COVID-19: How Korea Responded to a Pandemic using ICT ROK Ministry of Economy and Finance. Sejong, Korea.

Ministry of Economy and Finance, 2020. Flattening the Curve on COVID-19: How Korea Responded to a Pandemic using ICT. Sejong, Korea.

Nielsen, 2020. Concerns about COVID-19 Push U.S. E-Commerce Boundaries. Available at: https://www.nielsen.com/ us/en/insights/article/2020/concerns-about-covid-19-push-u-s-e-commerce-boundaries/

Organization for Economic Cooperation and Development [OECD], 2020. Leveraging Digital Trade to Fight the Consequences of COVID-19. Paris, France.

Porges A., Enders, A., 2016. Data Moving Across Borders: The Future of Digital Trade Policy. International Centre for Trade and Sustainable Development (ICTSD), Geneva, Switzerland.

Samet, A. 2020. United States ecommerce will rise 18\% this year amid the coronavirus pandemic. Business Insider. Available at: https://www.businessinsider.com/us-ecommerce-report-2020

Ungerer, C, Portugal, A. 2020. Leveraging E-Commerce in the Fight against COVID-19. Brookings. Available at: https://www.brookings.edu/blog/future-development/2020/04/27/leveraging-e-commerce-in-the-fight-against-covid-19/

United Nations Development Programme [UNDP], 2020. Survey on Impact of COVID-19 on Enterprises. Geneva, Switzerland.

Wang, S., 2018. OECD discussion on technical regulation on innovative digital basis. Law and Economic Regulation, 11, 378383.

World Bank, 2020. Recommendations to Leverage E-Commerce during the Covid-19 Crisis. Washington, DC.

World Economic Forum, 2020a. 5 Ways to Advance Digital Trade in the Post-COVID World. Geneva, Switzerland.

World Economic Forum, 2020b. COVID-19: The True Test of ASEAN Youth's Resilience and Adaptability Impact of Social Distancing on ASEAN Youth. Geneva, Switzerland.

World Trade Organization [WTO], 2020. E-commerce, Trade and the Covid-19 Pandemic. Geneva, Switzerland. 